\title{
Hospital Employer Attractiveness Considering the Increasing Shortage of Skilled Medical Professionals-A German Review
}

\author{
Joachim Merk ${ }^{1}$, Anke Rahmel ${ }^{2}$ \\ ${ }^{1}$ SRH Fernhochschule, The Mobile University, Beruf, Germany \\ ${ }^{2}$ Aalen University, Aalen, Germany \\ Email: Anke.Rahmel@hs-aalen.de
}

How to cite this paper: Merk, J. and Rahmel, A. (2016) Hospital Employer Attractiveness Considering the Increasing Shortage of Skilled Medical Professionals-A German Review. Journal of Biosciences and Medicines, 4, 1-10.

http://dx.doi.org/10.4236/jbm.2016.412001

Received: September 13, 2016 Accepted: November 24, 2016

Published: December 1, 2016

\begin{abstract}
The main goal of this review is to give an overview of scientific publications concerning the employer attractiveness of German hospitals from the perspective of medical doctors in order to identify future research possibilities. After a summary of central problems concerning the German health sector and its current challenges, the study design behind the systematic content analysis as well as its criteria are presented. Selected results describe characteristics of expert literature for employer attractiveness in general, the attractiveness of German hospitals as employers ("hospital employer attractiveness" for short) as well as employer attractiveness from a medical doctor's point of view. For each of these areas, focal points of research and main results are summarized and research gaps are pointed out.
\end{abstract}

\section{Keywords}

Systematic Content Analysis, Mainly German-Language Expert Literature, Hospital, Employer Attractiveness, Medical Professionals

\section{Central Problem and Challenges for Scientific Research}

This topic is relevant due to demographic developments in Germany. A lack of medical doctors is already perceptible. An inadequate medical provision will intensify in the following years and decades as a result of the "Dual Demographic Problem" which consists of a growing demand for staff in healthcare and a sinking supply of skilled medical labour. Replacement necessities and the general increase in the demand for doctors, as well as the inflow of new doctors, have significant influence on the number of available doctors and the lack of doctors as a whole [1]. 
The increasing demand for staff in health care can be ascribed to several reasons, e.g. demographic changes in an ageing society resulting in an increased demand for medical services [2] [3] or the amendment to the Arbeitszeitgesetz (working time law) which recognizes on-call duties as working time [1]. On the supply side, there is a continuing decline in medical professionals. The reasons for this development are e.g. a drop in the number of university graduates due to low birth rates [4] and a higher drop-out rate in medical studies [1] [3] coinciding with an increase in retirement entrances [2]. Until the year 202018,940 currently working doctors in hospitals and 51,800 contractual physicians will have finished working due to old age [1] [5]. Furthermore, the number of doctors who go abroad increased significantly in the last years (on average 2560 doctors per year since 2005) and medical experts increasingly search for work in alternative fields, e.g. in the pharmaceutical industry, scientific research or the insurance sector [2].

As a result there is an increased competition on the job market for medical professionals. Especially nonprofit hospitals increasingly need to face an economisation of social services and present themselves as attractive employers to the medical doctors available in the market in order to maintain their personnel performance capacity. Especially with respect to the following generations ("Generation Y" and "Generation Z") the perceived "attractiveness" of a potential employer as a basis of decision-making becomes more and more important for working place choices. Employer attractiveness is defined as "the envisioned benefits that a potential employee sees in working for a specific organization" by Berthon, Ewing and Hah [6]. The target of a strategic process of Employer Branding is the Employer Brand.

In the future, increasingly scarce personnel medical resources are an important forthcoming challenge for hospitals due to their high personnel intensity and the service character of the health sector. The establishment of an employer brand and hospital employer attractiveness are tested methods to encounter these difficulties. The present review show the current state of research for this topic as well as perspectives for future research projects from the point of view of (nonprofit) hospitals.

\section{Objective and Study Design}

This review is a systematic content analysis of mainly German-language expert literature on the subject and scientific studies of employer attractiveness with or without a focus on medical doctors. Content analysis is defined as an empirical approach to describe content-based and formal characteristics of messages in a systematic, inter subjective and transparent way; often with the goal of creating a basis for an interpretative inference [7]. The observations are focussed on the situation of medical doctors. The objective is to present the current state of research in a comprehensive and structured way to identify potential fields of research and further resource mobilisation for the research subject of doctor shortages in hospitals.

The included publications are structured systematically into 18 categories and will be analysed comprehensively according to the following criteria:

- temporal placement and content of the publications: 
overview of amount and development of publications over time.

focal points and und research topics (chronologically).

- design, methodology and theoretical foundation of the publications:

$>$ rates of theoretical and empirical works.

$>$ study types and research methods.

$>$ test subjects and study participants.

$>$ models and theoretical references.

- context and classification of the literature:

$>$ references to sector and occupational group.

$>$ country of origin and publication.

\section{Selected Results}

\subsection{Literature Survey}

In total, 283 publications were included in the systematic structuring and analysis. The publications can be differentiated using the criteria "research topic" on the one hand and "publication type" on the other hand-resulting in a matrix with 15 categories (see Figure 1).

Additionally, the systematic structuring of the publications used the following three categories:

- studies about personnel/human resources (7 publications).

- studies about hospitals (9 publications).

- websites (8 publications).

Consequently, the literature is systematized using 18 categories as a structural basis for later analysis. As Figure 1 shows, publications are focussed on primary statistics and theoretical works on employer attractiveness in general so far.

\subsection{Employer Attractiveness in General}

The first relevant publication in this context was the primary statistical research work "The Employer Brand" by Tim Ambler and Simon Barrow released in the year 1996. However, it was only as of 2008 that interest in this topic grew and the number of publications increased sharply. The publications show a wide range of contents, though the following focus areas can be identified:

- factors that influence an organisation's attractiveness, reputation and image.

- theoretical basis and implementation (process) of employer branding to establish an

\begin{tabular}{|r|c|c|c|c|c|}
\cline { 2 - 6 } $\begin{array}{r}\text { employer attractiveness } \\
\text { in general }\end{array}$ & 34 & 69 & 11 & 46 & 47 \\
\cline { 2 - 6 } $\begin{array}{r}\text { hospital employer } \\
\text { attractiveness }\end{array}$ & 6 & 4 & & 10 & 16 \\
\cline { 2 - 6 } $\begin{array}{r}\text { employer attractiveness for } \\
\text { medical doctors }\end{array}$ & 12 & 3 & 1 \\
\cline { 2 - 6 } & primary statistics secondary & \multicolumn{2}{c|}{ theory } & others \\
books statics
\end{tabular}

Figure 1. Literature classification. 
employer brand and increase employer attractiveness.

- factors and means to influence employer attractiveness, application intentions and employer brands, e.g. family friendliness of companies.

- requirements for an attractive employer, employer competition und employer rankings.

- requirements inventory for the implementation and application of employer branding and employer attractiveness in practice.

- employer attractiveness for small and medium-sized enterprises.

- internationalization of an employer brand and international recruitment of skilled professionals.

About 50 percent of publications in this field are primary statistical studies, about 42 percent are of a theoretical nature and only about 8 percent are secondary-empirical works. Primary statistical works mainly use quantitative research methodologies (75 percent). More than half of the studies use a variety of students from different fields of study as test subjects, with economics and management students as the biggest groups. The perspective of recruitment clearly is the focal point of most publications. In very few works, there is a sector- or occupational group-centered survey or analysis (only about 15 percent of publications). There are only about 30 percent of publications which contain scientific study approaches and a theoretical scientific foundation, as well. Oftentimes, the authors come from an scientific economics background, often with an emphasis on human resource management or marketing, they usually teach students full time or part time and about a fifth of them work for a consulting company. Foreign publications come from a big range of countries, most of them are from the United States.

\subsection{Hospital Employer Attractiveness}

An increased interest in the topic of "hospital employer attractiveness" only exists since the year 2010. The most common subjects of publications are family friendliness of hospitals, the importance of corporate culture, hospital branding and employer branding, staff recruitment and personnel commitment as well as human resource concepts for hospitals, the importance of employer attractiveness in both theory and in practice and employer attractiveness from the perspective of Generation Y. The key areas of publications in the field of hospital employer attractiveness so far are book chapters and theoretic scientific and popular scientific articles which are quite strongly guided by the latest general findings. There is only a relatively small amount of primary statistical works; quantitative research methods are applied in a big majority of publications while there are hardly any secondary empirical works. Similar to the literature on general employer attractiveness, hospital employer attractiveness publications don't contain any theoretic references and only traces of a scientific basis, most of the time. Usually, the authors have a background in health science or practical experiences in health care.

\subsection{Employer Attractiveness from a Doctor's Point of View}

Publications on employer attractiveness from the perspective of the occupational group 
of medical doctors exist since 2005. Common contents of the publications are (prospective) doctors' point of views on employer attractiveness, employer branding, the influence of job advertisements information on application intentions, expectations of prospective doctors towards their profession, family and their work-life-balance, employer attractiveness from the perspective of Generation $\mathrm{Y}$ and general approaches to solve the problem of doctor shortages. The studies performed on this subject area were for the most part primary statistical publications. However, there is only a small amount of publications and all of them used quantitative research methods. Most of the time, test subjects were medical students and a recruitment perspective proves to be quite dominant. A focus on single medical disciplines is rare to find; most of the time, different disciplines and hierarchy levels are viewed as a whole. Here again there is hardly any scientific foundation. The authors (mainly groups of authors) usually have a medical and/or economic background.

\section{Reflexion and Critical Appraisal}

\subsection{General Findings on Employer Attractiveness}

The following main topics can be identified for studies that deal with employer attractiveness in general: survey of target groups in the job market to gather information about their requirements, preferences, values, goals, preferred information and communication channels as well as their take on the attractiveness of certain companies or their perception of different employer brands and images; surveys on the characteristics of a preferred employer and creating a desired profile and preference lists concerning the most important employer attractiveness factors; studies on the impact of single factors on the attractiveness of certain sectors and functions, e.g. the attractiveness of family businesses in comparison to large enterprises; theory and realization of employer branding, e.g. requirements inventory for the establishment of a practical employer brand. The present review mainly focuses on relevant factors of employer attractiveness, influences on attractive features as an employer and preferences of the target group.

The top factors of employer attractiveness relate to the direct work situation and, therefore, factors that can be influenced by human resources. In contrast, product- and enterprise-specific factors, like product or service quality or the size of a company, don't seem to be of prime importance.

In the general studies (comparison between 10 studies from 2003 to 2012, e.g. [8] [9] [10] [11]) the following factors can be identified as the most important for employer attractiveness:

- career and promotion opportunities.

- training and development opportunities.

- work environment.

- work task (interesting, challenging, enjoyable etc.).

- compensation (appropriate, performance-oriented etc.).

However, there are differences depending on which groups of persons were surveyed. 
The following factors and characteristics can be identified as the most important influences on the assessment of employer attractiveness: value orientation of the generations (traditionals, baby boomers, Generation X, Generation Y, Generation Z), occupational group or field of study, phase of life, personality traits, sex, age and occupational status (e.g. students or employed persons, employer or employee, high potential or professional or standard performer). The interest profile of applicants are composed from different factors; most important among them are the value orientation of the generation, the occupation group and the phase of life as well as the personality structure. Moreover, differences in the technique used to collect the data can be identified. As a result of techniques of active naming (in contrast to marking with a cross) there are variations in ranking sequences, mostly due to the factor compensation which is ranked as much more important with active naming. Also, factors and characteristics of employer attractiveness and their importance are rated differently by employers and employees. Predominantly, the studies represent a recruitment perspective; there are no isolated considerations of different perspectives, although indications can be found that different factors of employee recruitment, commitment and motivation are important. Cultural and country-specific factors have an influence, as well.

\subsection{Identify the Headings Findings on Hospital Employer Attractiveness}

So far, there are only a few primary statistical studies on hospital employer attractiveness; the existing studies focus on instruments for staff recruitment and commitment. Figure 2 presents the instruments that are used most often in hospitals to recruit and commit employees. The summary is based on an analysis of 5 studies from the period between 2010 and 2013 (e.g. [1] [12] [13]).

Studies also show that work reality and expectations of (prospective) doctors differ strongly, even though the importance of different factors of employee commitment are well-known.

\subsection{Findings from the Perspective of Doctors}

Only a few studies concern the views of medical doctors who are already in employment.

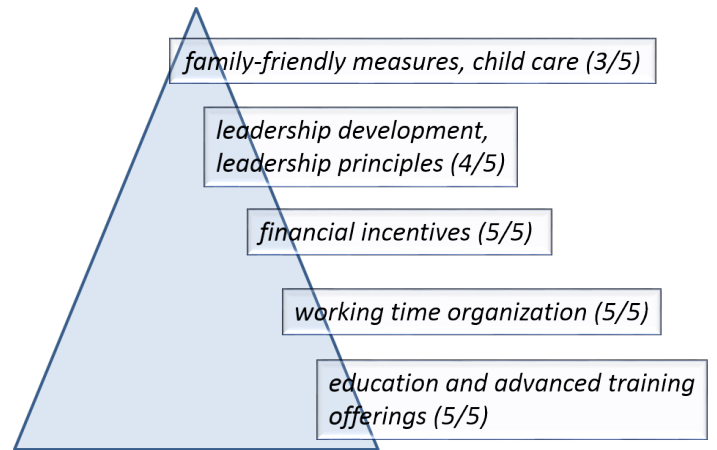

Figure 2. Instruments for staff recruitment and commitment most often used. 
Most of the publications present the perspective of students or graduates. The few studies which deal with commitment and motivation show that the identification with hospitals as employers is quite low and the readiness to switch employers is rather high. A comparison of studies from the period of 2005 to 2013 (e.g. [14] [15] [16]) shows that there is a particularly great dissatisfaction among prospective doctors with the following factors:

- difficulties in reconciling professional and family life.

- inappropriate, bad or very limited compensation.

- working time organization (excessively long hours of work, not enough spare time, insufficient compensation for overtime).

- stress and heavy workload.

- rigid hierarchies.

- too much bureaucracy.

As far as employer attractiveness from doctors' point of views are concerned, factors that can be influenced by personnel policy are significant, while factors less connected to personnel policy, like a hospital's levels of medical care, ownership or size are rather unimportant. A good working atmosphere can be identified as the sole cross-study factor of attractiveness. Training opportunities and the reconciling of work and family life are other factors that are repeatedly mentioned. Apart from these exceptions, there are rather big differences depending on field, hierarchy level and sex of the target group; there are also big differences between students and working doctors [14]-[19].

Some findings from general scientific research can be transferred to the research subject of "doctors in hospitals", e.g. theoretical backgrounds and concepts, while the only major difference between sectors lies in the definition of the applicant target group and the resulting specific catalogue of measures.

It is very likely that the general influencing factors on employer attractiveness can be transferred to the hospital sector as well as findings from this area that can be seen as relatively stable across sectors or studies that collect data from several sectors and different occupational groups. Value orientations of generations, stages of life and personality structures are examples for rather stable and cross-sectoral factors. Studies also came to the cross-sectoral conclusion that the most important factors of employer attractiveness relate to the direct work situation and a person's own working conditions factors that can be described as egoistical. From an applicant's point of view, factors like the company's product or services, size or other enterprise characteristics are not primary influences on employer attraction. It is very likely that this can be applied to the hospital sector. Different general studies also confirm the positive influence of factors like corporate social responsibility, company reputation and family friendliness on employer and organization attractiveness for different sectors and occupational groups these results also can be applied to hospitals with a high degree of certainty.

However, some areas should be researched in isolation and from the perspective of medical doctors. Both the occupational group and the studying choices have a big influence on the importance of single factors of attractiveness. In different studies, there 
are rather big differences between occupational groups as well as between an overall view and the view of a specific occupational group, concerning relevant characteristics of employer attractiveness. For that reason, factors that are relevant for a specific occupational group cannot be transferred to another occupational group like medical doctors directly. It is crucial to conduct a study which examines relevant factors in an occupational group-specific analysis. A similar recommendation should be made for studies on employer attractiveness from different countries. Studies show that there are different country-specific and cultural priorities and assessments by candidates and the attractiveness of different factors is rated differently, too. These studies cannot be transferred to Germany and, more particularly, to the hospital sector, since these areas show very different characteristics in a lot of countries.

\section{Potential Research Areas, Future Challenges and Conclusion}

In general, there is a need to expand scientific research on the subject, because existing publications are focussed on practice-oriented studies. The present studies also cover the view of medical students primarily, while working situations and employer attractiveness from a working doctor's perspective are hardly illuminated. That is why it is important to redirect the focus of future research activities towards professionally experienced and already employed doctors, because studies indicate that there are big differences between students and employees. Furthermore, studies are primarily concerned with external target groups and a recruitment perspective. The perspectives of commitment and motivation should be examined more thoroughly, since according to study results, identification with the employer is low amongst doctors and commitment is not very high either with a high willingness to switch employers. Factors of employer attractiveness and preferences should be measured separately for potential and current employees, because there are (at least in part) variations on the factors for recruitment, commitment and motivation.

Previous studies point to the fact that there are differences concerning requirements and preferences between different specialist medical groups among doctors since they face different expectations and demands in daily work as well. In any case, there should be more specialist medical group-specific studies on employer attractiveness, also to determine, how big the differences actually are as well as which findings are valid for which doctor group (and which are not).

The same can be said about hospital hierarchy levels: studies show different results for working satisfaction and preferred employer characteristics depending on the level. Both the relevance and the extent of this difference should be examined more closely, so employer branding efforts can be geared towards target groups. Differences between sexes should also be examined considering the continuing feminization of medicine.

In addition, there are further research opportunities to be mentioned, e.g. the analysis of the actual effects of single characteristics that were identified as important for hospital employer attractiveness and their control parameters, since there are only studies on the family friendliness of hospitals so far as well as on the establishment of 
international employer brands by hospitals and foreign doctors' requirements on German hospitals.

Moreover, a scientific confirmation of the influences of hospital and service brands and the quality of treatment on employer attractiveness is still pending. Similarly, there is still no evidence that the shortage of doctors is lower in hospitals with an established employer brand as opposed to hospitals without an established employer brand.

Since the lack of doctors is expected to increase even further, the research area "employer attractiveness from doctors' point of views" will be highly relevant and current. Several findings can be transferred from general studies to the research subject of medical doctors in hospitals, many areas must be examined more distinctively, however.

\section{References}

[1] Blum, K. and Löffert, S. (2010) Ärztemangel im Krankenhaus, Ausmaß-Ursachen-Gegenmaßnahmen. Forschungsgutachten im Auftrag der Deutschen Krankenhausgesellschaf, Düsseldorf.

[2] Kopetsch, T. (2010) Dem deutschen Gesundheitswesen gehen die Ärzte aus! Studie zur Altersstruktur- und Arztzahlentwicklung. 5. Aufl., Berlin.

[3] Bundesministerium für Familie, Senioren, Frauen und Jugend (2009) Vereinbarkeit von Familie und Beruf im Krankenhaus.

[4] Kamp, A., König, J.E., Müller, S. And Plücker, W. (2011) Personalmangel versus Arbeitgeberattraktivität: Studienergebnisse offenbaren mangelhafte Personalkonzepte in deutschen Krankenhäusern. Arzt und Krankenhaus, 84, 334-338.

[5] Pricewaterhouse Coopers (2010) Fachkräftemangel-stationärer und ambulanter Bereich bis zum Jahr 2030. Frankfurt am Main.

[6] Berthon, P., Ewing, M. and Hah, L.L. (2005) Captivating Company: Dimensions of Attractiveness in Employer Branding. International Journal of Advertising, 24, 151-172.

[7] Früh, W. (1998) Inhaltsanalyse-Theorie und Praxis. 4. Aufl., Konstanz.

[8] Lewandowski, A. and Liebig, C. (2004) Determinanten der Arbeitgeberwahl und Relevanz des Personalimages für die Bewerbungsabsicht, Fallstudie am Beispiel der Deutschen Bundesbank. Mannheimer Beiträge zur Wirtschafts- und Organisationspsychologie, 19, 1528.

[9] Schleiter, A. andArmutat, S. (2004) Was Arbeitgeber attraktiv macht. Praxispapiere.

[10] Kirchgeorg, M. and Günther, E. (2006) Employer Brands zur Unternehmensprofilierung im Personalmarkt-eine Analyse der Wahrnehmung von Unternehmensmarken auf der Grundlage einer deutschlandweiten Befragung von High Potentials.

[11] Georg, K. and Rüsen, T.A. (2011) Attraktivität von Familienunternehmen als ArbeitgeberEine empirische Untersuchung der Sicht junger Akademiker.

[12] Schubert, P. (2012) Was Arbeitgeber attraktiv macht. F \& W, Führen und Wirtschaften im Krankenhaus, 4, 396-398.

[13] Teuber, I. and Möller, O. (2013) Strategiestudie 2013: Herausforderungen fürkommunale Krankenhäuser in Deutschland.

[14] BVMD (2005) Umfrage Wie wünscht Ihr Euch eure Arbeitsbedingungen im Krankenhaus.

[15] Buxel, H. (2009) Der ärztliche Nachwuchs ist unzufrieden. Deutsches Ärzteblatt, 37, A1790- 
A1793.

[16] Buxel, H. (2013) Was Ärzte zufriedener macht. Deutsches Ärzteblatt, 11, A494-A498.

[17] Mitlacher, L.W. and Welker, A. (2011) Die Attraktivität von Arbeitsbedingungen im Gesundheitswesen. Der Betriebswirt, 3, 27-30.

[18] Schmidt, K., Meyer, J., Liebeneiner, J., Schmidt, C.E. and Hüttenbrink, K.B. (2012) Generation Y in der HNO, Führung einer neuen Generation von Ärzten. HNO, 16, 993-1002.

[19] Zippel, C., Güde, M. And Bohner-Joschko, S. (2012) Was der Ärztenachwuchs erwartet. Das Krankenhaus, 11, 1128-1134.

Submit or recommend next manuscript to SCIRP and we will provide best service for you:

Accepting pre-submission inquiries through Email, Facebook, LinkedIn, Twitter, etc.

A wide selection of journals (inclusive of 9 subjects, more than 200 journals)

Providing 24-hour high-quality service

User-friendly online submission system

Fair and swift peer-review system

Efficient typesetting and proofreading procedure

Display of the result of downloads and visits, as well as the number of cited articles

Maximum dissemination of your research work

Submit your manuscript at: http://papersubmission.scirp.org/

Or contact jbm@scirp.org 